\title{
Design studio challenge, as a creativity fostering tool for product Design students
}

\author{
Dr.Aziza Maher Abou Elsoud
}

lecturer, at Faculty of Applied Arts, Product Design Department, October 6 University, Egypt.

DOI: 10.21608/jdsaa.2021.30287.1048

Keywords:

Design teaching, creativity, Design Challenge, Design studio, time management.

\begin{abstract}
:
Improving students' creativity skills is design instructors' dream, that's why there are many techniques to achieve that, as a design instructor you want your students to think out of the box, to be motivated and competitive, you want to make sure they make the best out of the design studio time.

Students waiting for the professor feedback on their projects would be irritating, as the time you spend with each one would mean a wasted time for the others, they would be anxious, and worried about feedback on their work, so they just sit waiting for calling their names for follow up.

Instructors' life dream is to have great time management inside the design studio, students gaining knowledge, benefitting from lecture time, have one on one time with each student, making sure they are on the right track.

Design challenges is a well-known activity in design communities, it simply aims to keep designers motivated, some time it's time controlled, in others, its topic controlled.

The study aims to discover the potentials resulting from applying design challenges in classroom while inspiring the students for design thinking, how will this be applied? is this going to improve their creativity skills? would this help the instructor for better design studio time management?

The experiment is taking place during product design studio in, College of Applied Arts, Product Design Department, the experiment is documented using videos and photos.
\end{abstract}




\section{1- Introduction}

A design challenge is a case of calling for design solutions for a certain problem or product, from designers from related fields, some companies do it in Design job interviews to measure the candidates abilities, others do it for promoting themselves as active society partners, institutions like ford run design competitions among high school students to promote creative thinking, Yanko Design runs it to collect best designers work, making them available for companies and start up projects'. And whatever the reason is, they strongly exist.

Being creative is all about being able to let go of all the mind abilities, in order to come out with a brandnew Idea of anything mostly, heard, seen, touched, or tasted. The early stages of creativity are characterized by the existence of rather fuzzy implicit ideas, plenty of divergent thinking, a tolerance of ambiguity and the use of intuition. The later stages of creativity see more precise and explicit ideas, a tendency for convergent thinking, with a greater use of analysis and a concern for tests that prove consistency.

This study focuses on creativity fostering for design students during the time of design studio. which is a common name of design-oriented course in product design education.

There are many reasons for students to improve their creativity, their ability to succeed in the market place is obviously one of them. In recent years, the most developed countries have been paying great attention to creativity of products as a great competing factor, that can help their economy stand strong in the global market and that what made design a great tool for economic added value for many of these countries. If a country wants to claim a good position in the competition of global economy, product design curriculum should pay great attention to involve improving students' creativity skills. Most product Design instructors dream of having creative students, certainly would like to accomplish that aim while being able to follow up their students' projects progress, give them a space for their own design character to grow and shape in the best possible way, and successfully accomplish that during the studio time. The study is experimenting with the role design challenges during the design studio time, as a tool to foster students creativity skills in general, and in their projects in particular. The experiment took place with second year students, in product design studio for 10 weeks, sessions have been filmed and students work was photographed and assessed. The results showed that, creativity thinking level has transformed for better in the case of majority of the students.

\section{2- What is a design challenge?}

A design challenge is a competition where an institution, company or person puts out a call for designers to solve a specific problem. Usually, these problems are related to society and require talented designers to create innovative and practical solutions to these problems.

When an institution or a company announces or calls for a design challenge it simply means there is a problem that need to be solved or a product that needs to be developed, and somehow talented designers are needed for it, sometimes it's about discovering those designers.

Some famous company encouraging young designers to participate like the case of Rocca design challenge that took place in 2019, in many countries like Australia, Malaysia 2019, Bulgaria 2019, Barcelona 2019, Indonesia 2019, figure(1), it also could be done during a job interview, like the case of UX Design challenges, in which a first and second interview were combined into one, and it started with the design challenge which had a time limit of 15 minutes! The candidate was given a print out of the challenge and worked it through with one of the interviewers. The challenge itself was to design a clock for a persona of someone that was blind.

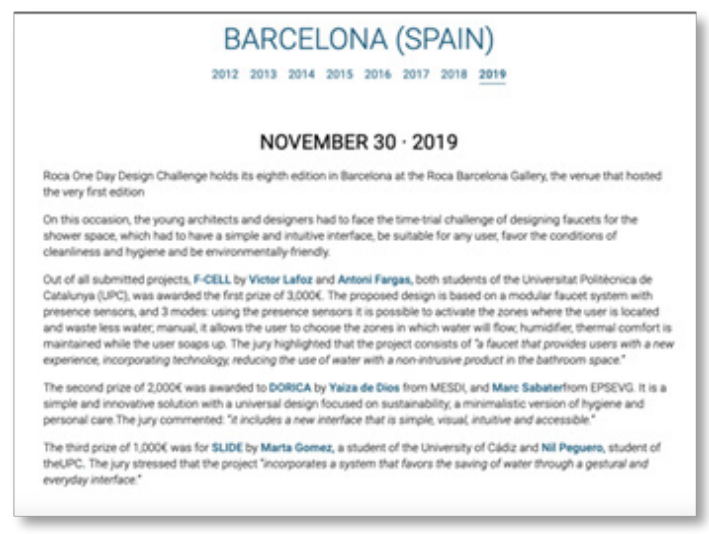




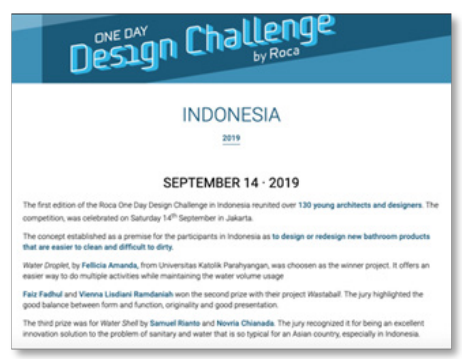

Figure 1(1): Rocca design challenge 2019 in more than one country

For designers such a challenge is a way to stay motivated, inspired and to work with others in a motivational atmosphere, team members get to know each other, learn the real meaning of trust and supporting each other, respecting the vision of each other, and certainly learn how to integrate their qualities of strength and compensate each other's weaknesses, considering the fact that during the challenge they are one thing if they win they win together and if they lose they lose together. Design challenges can also help designers share experiences and techniques, people from different schools of design thinking are going to work together side by side, there is a big chance that they would learn the skills of each other, despite of the fact they may not see eye to eye about each other problem solving process. Design challenge could be stressful for those who cannot work under pressure and if it is sort of big and wide, some of the designers who haven't won's ideas could be copied.

\section{3- Implementing design challenges}

Implementing a design challenge could be done in a few ways. It could be a government issue sometimes, for example when The Design council as a government body volunteered to be one of UK advisors in Design, one of the design challenges they launched in October 2009, was Design for Patient Dignity in cooperation with the Department of Health and healthcare specialists from the Royal College of Art Helen Hamlyn Centre to develop new designs, (figure2) concerning patient dignity when being hospitalized.

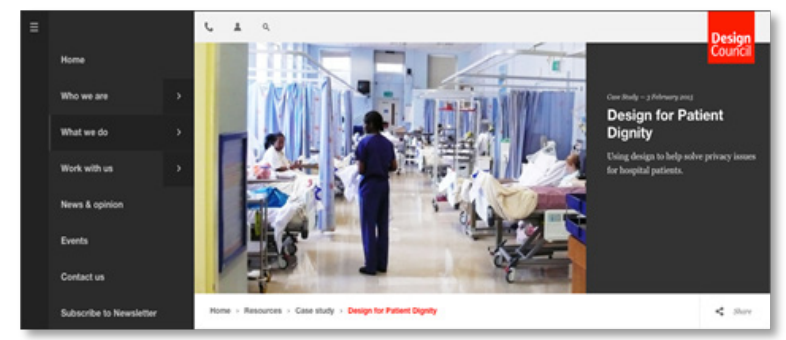

Figure 2(2): Design council: patient dignity challenge on their website
On their webpage they highlighted the challenge in a few points like, problem, insight, constraints, deadline, teams. The challenge results on their website shows how can choosing the right title bring variety of design solutions to the table, and motivate designers from different field to participate, which assures that choosing the right challenge title would make a difference for the call and that Designers' work could be very creative in that they can come up with solutions to help sculpture a better word (figure3).

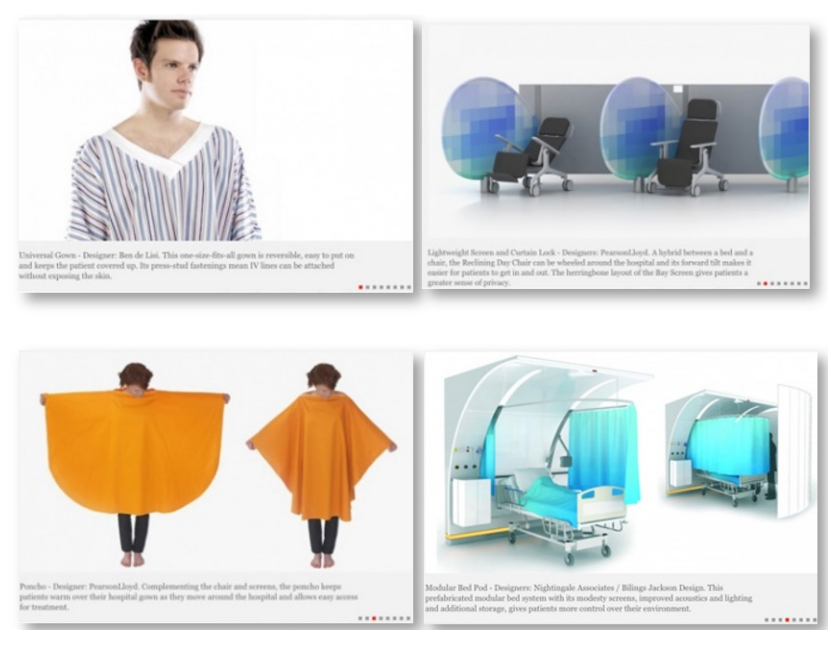

Figure 3(3): Variety of design fields answering to the challenge

\section{4- What is creativity?}

Creativity is considered an important part in the innovation process. A creative person is not only a gifted person, it is also a person that cares to learn and understand deeply what should be created whatever it is, meanwhile has the desire to analyze, question and wonder about all the existing facts. Design students should never take anything for granted in order to be creative and think out of the box, and give their imagination a chance to take part in their ideas but first they should get the power of knowledge then, use imagination to discover how to free themselves from that knowledge in a balanced way. Although creativity may just happen in a fraction of a minute, it is a result of a long process and a hard work.

It is essential that learners have sufficient understanding of everything about the product they are required to design, starting from, what it does, how it works, how it's made, moving to how it's connected to the user, the environment, fashion trends, and so many other factors as well.

Due to the complicated nature of practicing design that combines form, functions, and all the available technologies and materials, it should not be forgotten that Intuition represents the heart of the creativity process. 


\section{4-1- Creativity in the Design Studio}

Creativity in the design process happens as a camera flash just hits the designer, he sees something like a clear vision of a solution for his design problem whatever it is, this is the moment when the creative step', emerges. Every designer knows that as much as it could be grasped suddenly, it often occurs after the designer discover the steps in his design process. Solving Design problem needs creativity other than knowledge and expertise. Creative thinking requires the perception of a problem or event from a new perspective outside of the usual. Designers adopt different techniques, tools or analytical methods in order to get more creativity in their work. Nailing creativity requires approaching it from three main aspects, personal creativity, process creativity and product creativity (1).

Being in the Design Studio, students go through a unique kind of a challenge, experiencing different kinds of practices and certainly facing a new kind of learning environment. They are required to absorb new concepts and ideas while performing two important activities one of them is to learn how to design the other is to practice the activity of design. Actually, there are important qualities gained by the students through these two activities one of them is developing communication skills either with their peers or their design instructors, in a way, communication is a keyword in the definition of a design studio (2). Students create alternative design solutions in the design process. Students brainstorm with different ideas and suggestions to evaluate design

proposals while taking into consideration critique of the instructor in this process.

In Applied Arts, instructors should understand their role is not only to teach students to be designers but to be learners in the first place, they need to know how to collect the data they need in an effective way. Effective learning appears to be the key not only to success in education but also in a fast-moving working environment. instructors teach students to engage in a strategy of learning in which they are not skilled. The learning preferences of design students, as might be expected, are action-oriented and revolve around imagination and emotion (3).

\section{5- Details of the Design Challenge:}

\section{5-1 Teams structure and description of the chal-} lenge concept

- a.Total number of the students was 32 , the plan was to have 4 teams working on different topics, team leaders were picked by the course instructor depending on previous knowledge of students 'abilities and their previous design courses achievements, so basically top of class students were picked as team leaders, and they were told to form their own teams later on.

- b. A briefed description of the whole idea of what a design challenge means was given to the students by the instructor and it was announced as a class studio activity assessed out of ten marks of the whole studio work final marking

- c. The design process to be adopted was explained in detail and many examples were given, actually those students applied it with the same instructor in an earlier design class, which made it easier for the instructor to explain

- d. Building the teams was assigned to the team leaders (in order to develop their decision-making skills)

- e. A meeting between the instructor and team leaders took place to inform them bout the know how team building techniques.

\section{5-2 General directions\& Restrictions}

Team leaders were asked to form teams of 8 , of their own choice, according to the criteria explained to them by the instructor. The idea was centered around dropping problems facing most of us in our daily life, so the students would be familiar with the problem and probably faced them in real life, the problems were announced in Design Studio then the students were asked to think as teams and choose a challenge that they would work on together as a team and they were told to sign up for that challenge as a team, and tablel shows their own choices.

\begin{tabular}{|c|c|l|}
\hline No. & Team & Problem to be solved \\
\hline 1 & 1 & $\begin{array}{l}\text { A crowded closet that in need of } \\
\text { regulation }\end{array}$ \\
\hline 2 & 2 & Messy fridge, needs to be organized \\
\hline 3 & 3 & $\begin{array}{l}\text { shoes are everywhere, storage } \\
\text { needed }\end{array}$ \\
\hline 4 & 4 & Messy student's desk \\
\hline
\end{tabular}

Table 1: design problems chosen by the teams 


\section{5-2-1 The following were explained to the teams}

- a. Teams were only allowed to make their sessions for the first two hours starting after the instructor intro, each studio time and they were asked to stop directly, after the two hours.

- b. Internet access was allowed during the studio time for the first 45 minutes unless extra time is needed then the instructor approval was needed.

- c. Manual sketching was a must for all teams (aiming to improve manual skills)

- d. Pencils, soft pastels\& Markers were allowed as sketching tools

- e. Digital 3D drawings were not allowed.

- f. Consulting instructor and/or assistant lectures was only allowed when necessary.

- g. Teams were allowed to brainstorm each other and discuss their projects among each other.

- h. Students were asked to submit their documents before leaving the studio, and any extra work at home was not allowed.

- i. Assistant lectures were following up and observing the teams' work and efforts without any interference unless badly needed.

\section{6- The Design process phases and timeline}

Seven design tasks were put for choice for the four groups, challenges were not announced in a form of designing a product but described as a problem, majority of us face in our daily lives

\begin{tabular}{|c|l|}
\hline No. & \multicolumn{1}{|c|}{ The design challenge } \\
\hline $\mathbf{1 -}$ & $\begin{array}{l}\text { A crowded closet that in need of } \\
\text { regulation }\end{array}$ \\
\hline 2- & Messy student's desk \\
\hline 3- & shoes are everywhere, storage needed \\
\hline $\mathbf{4 -}$ & $\begin{array}{l}\text { travelling suite case need to be } \\
\text { regulated }\end{array}$ \\
\hline $\mathbf{5 -}$ & Messy fridge, needs to be organized \\
\hline $\mathbf{6 -}$ & Dish\& spoon drainer \\
\hline 7- & laundry basket in a dorm \\
\hline
\end{tabular}

Table 2: Complete offered design tasks

\begin{tabular}{|c|c|c|c|}
\hline $\begin{array}{l}\mathbf{N} \\
\mathbf{0 .}\end{array}$ & $\begin{array}{c}\text { phas } \\
\text { e }\end{array}$ & steps & period \\
\hline \multirow{3}{*}{$1-$} & \multirow{3}{*}{$\begin{array}{l}\text { Disco } \\
\text { very }\end{array}$} & Scenario\& personas & $\begin{array}{c}\text { Week } \\
2\end{array}$ \\
\hline & & $\begin{array}{l}\text { collecting Data about } \\
\text { similar products }\end{array}$ & $\begin{array}{c}\text { Week } \\
3\end{array}$ \\
\hline & & $\begin{array}{l}\text { product\& product design } \\
\text { analysis }\end{array}$ & $\begin{array}{c}\text { Week } \\
4\end{array}$ \\
\hline \multirow{3}{*}{$2-$} & \multirow{3}{*}{$\begin{array}{l}\text { Inter } \\
\text { preta } \\
\text { tion }\end{array}$} & $\begin{array}{c}\text { Analyzing the } \\
\text { product scenario } \\
\text { from product design } \\
\text { perspective. }\end{array}$ & $\begin{array}{l}\text { Week } \\
5\end{array}$ \\
\hline & & $\begin{array}{l}\text { Analyzing the product } \\
\text { problems from user's } \\
\text { perspective. }\end{array}$ & $\begin{array}{l}\text { Week } \\
5\end{array}$ \\
\hline & & $\begin{array}{l}\text { specifying design } \\
\text { requirements needed to be } \\
\text { achieved in the new } \\
\text { product }\end{array}$ & $\begin{array}{l}\text { Week } \\
6\end{array}$ \\
\hline \multirow{3}{*}{ 3- } & \multirow{3}{*}{$\begin{array}{l}\text { Crea } \\
\text { tion }\end{array}$} & Initial Ideas & $\begin{array}{c}\text { Week } \\
7 \\
\end{array}$ \\
\hline & & Modifying Ideas & $\begin{array}{c}\text { Week } \\
8\end{array}$ \\
\hline & & Choosing final Idea & $\begin{array}{c}\text { Week } \\
9\end{array}$ \\
\hline 4- & $\begin{array}{c}\text { final } \\
\text { prese } \\
\text { ntati } \\
\text { on }\end{array}$ & $\begin{array}{l}\text { Preparing final Idea to be } \\
\text { displayed for the whole } \\
\text { class in order to be } \\
\text { assessed by the instructor } \\
\text { and other students based } \\
\text { on final design } \\
\text { requirements delivered by } \\
\text { each team }\end{array}$ & $\begin{array}{c}\text { Week } \\
10\end{array}$ \\
\hline
\end{tabular}

Table 3: design process phases timeline

6-1 Phases of the design challenge process (the same design process students 'are following).

6-1-1 Phase 1: Discovery

a. Understanding the product and the users (Scenario\& personas).

b. collecting Data about similar products.

c. product\& product design analysis.

\section{6-1-2 Phase 2: Interpretation}

a. Analyzing the product scenario from product design perspective.

b. Analyzing the product problems from user's perspective.

c. specifying design requirements needed to be achieved in the new product

\section{6-1-3 Phase 3: Creation.}

a. Initial Ideas 
b. Modifying Ideas

c. Choosing final Idea (Using Design Requirements as revision list).

6-1-4 Phase 4: Final presentation.

a. Deciding best studio display technique.

b. Distributing duties among team members.

c. Preparing documents for final submission.

\section{6-2 Documenting the experiment}

6-2-1 Team 1(A crowded closet that in need of regulation)

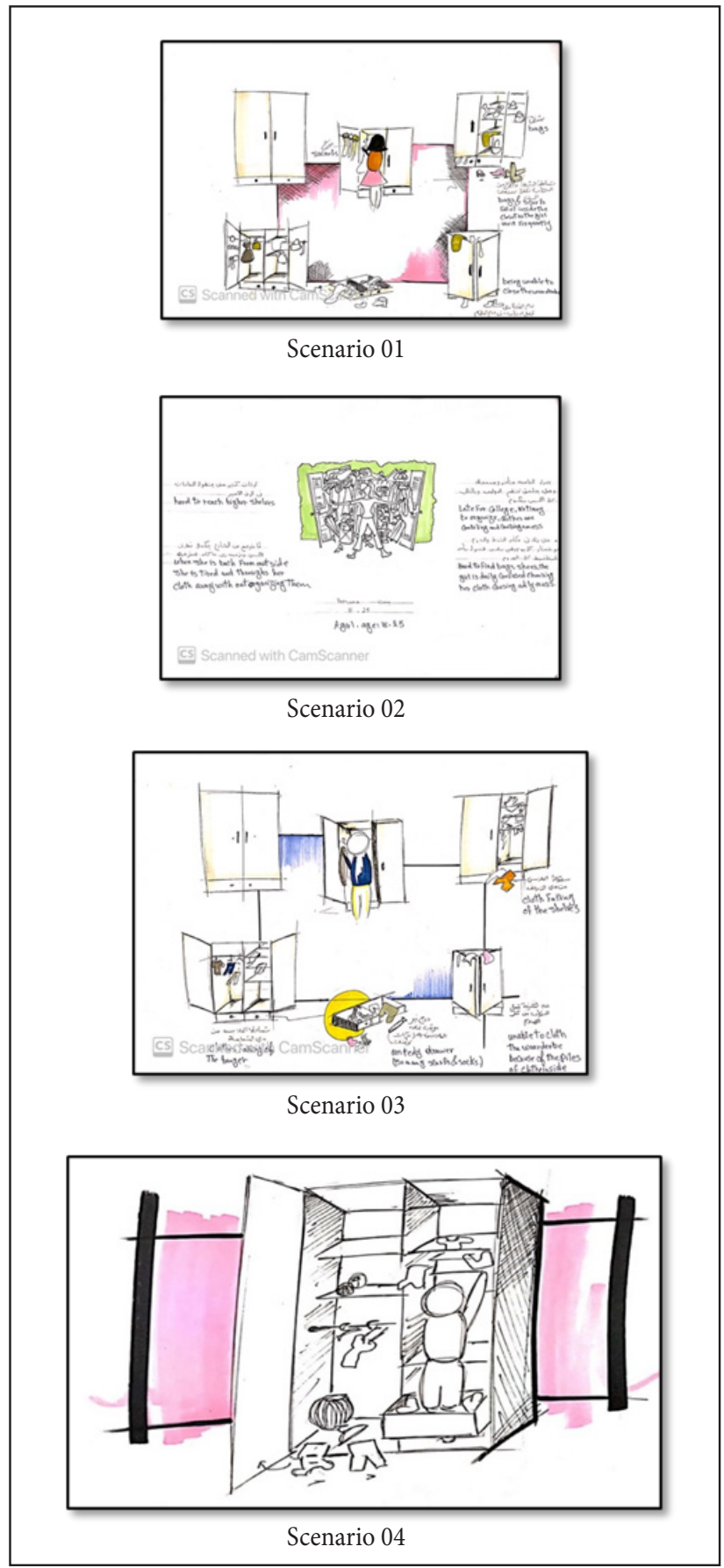

Figure 4: Scenarios showing the problems faced by different users

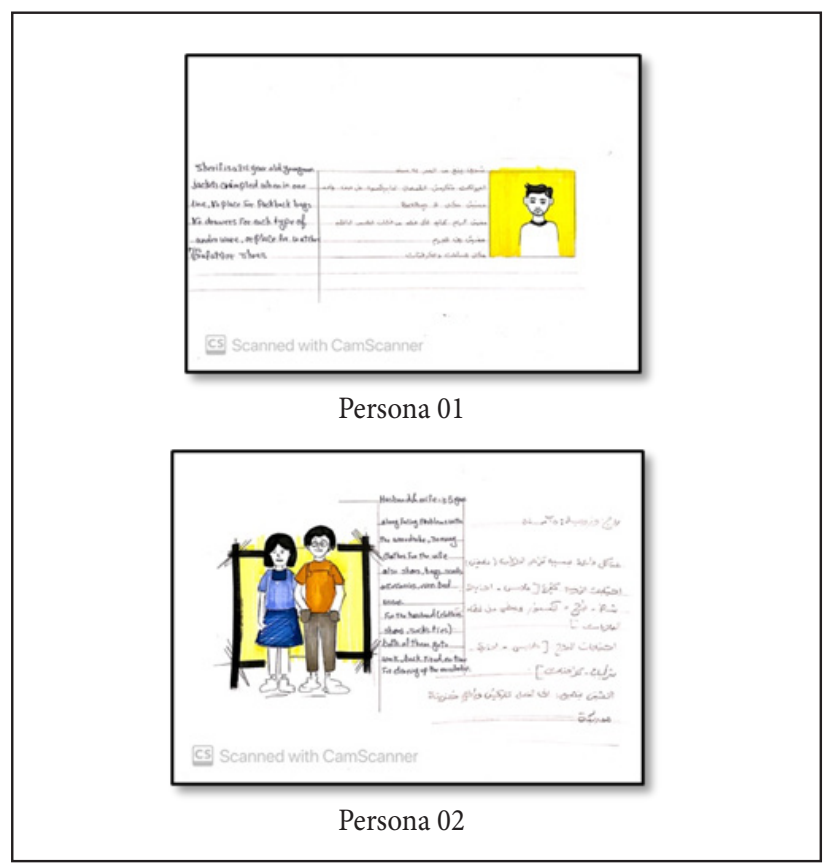

Figure 5: Persona
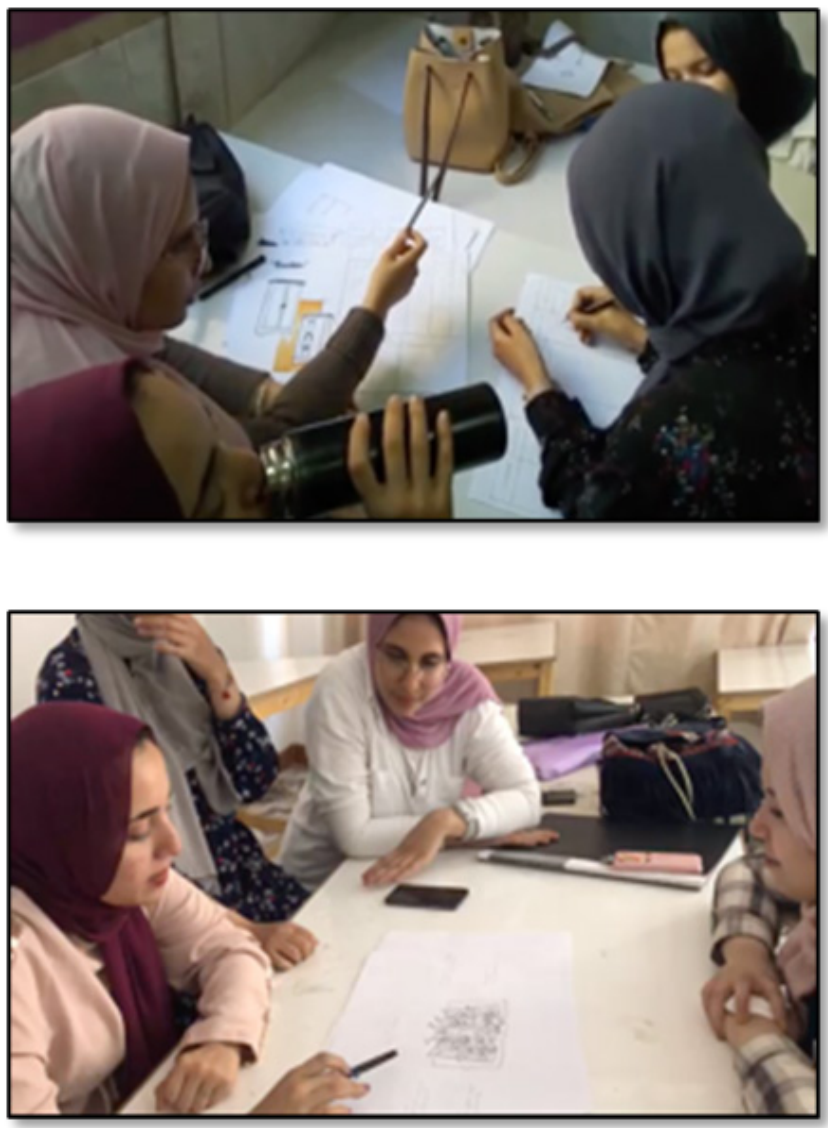

Figure 6: photos of the team during work sessions 


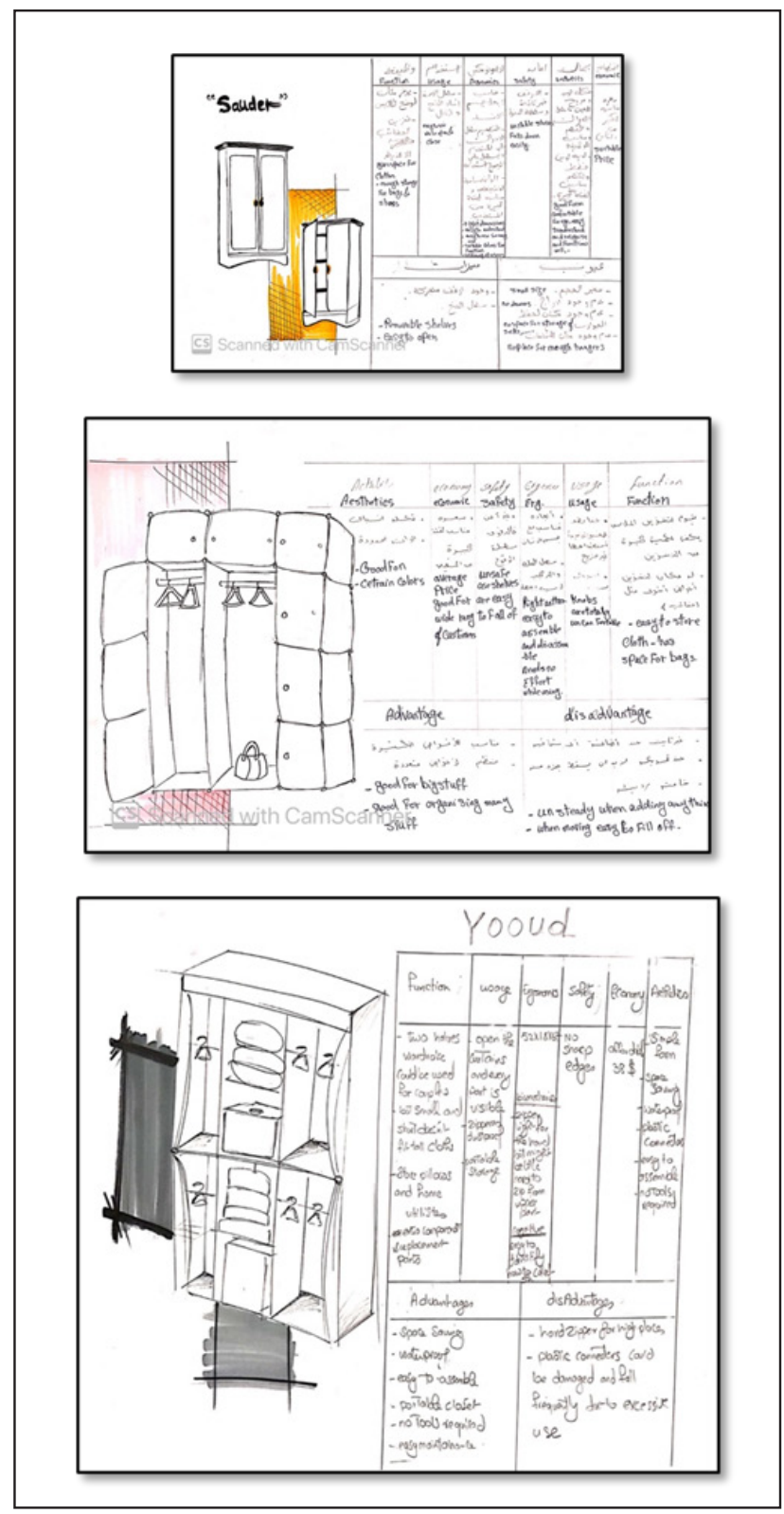

Figure 7: Product analysis

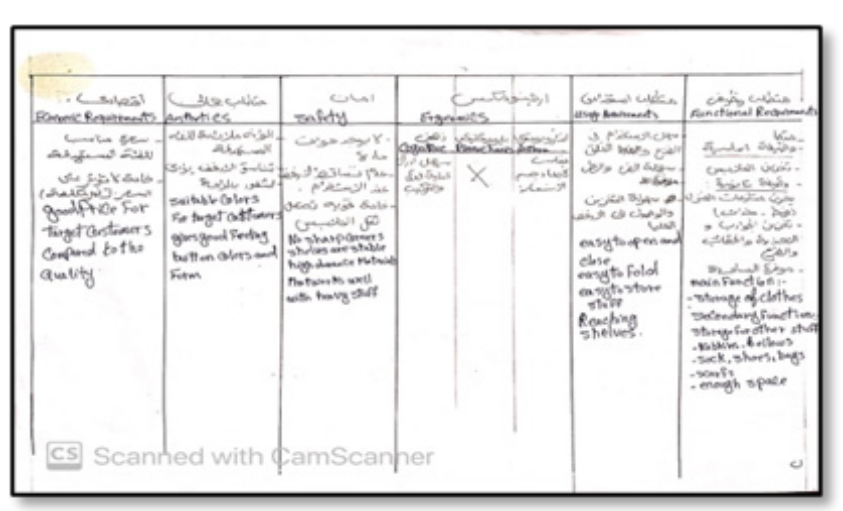

Figure 8: Final Design Requirements

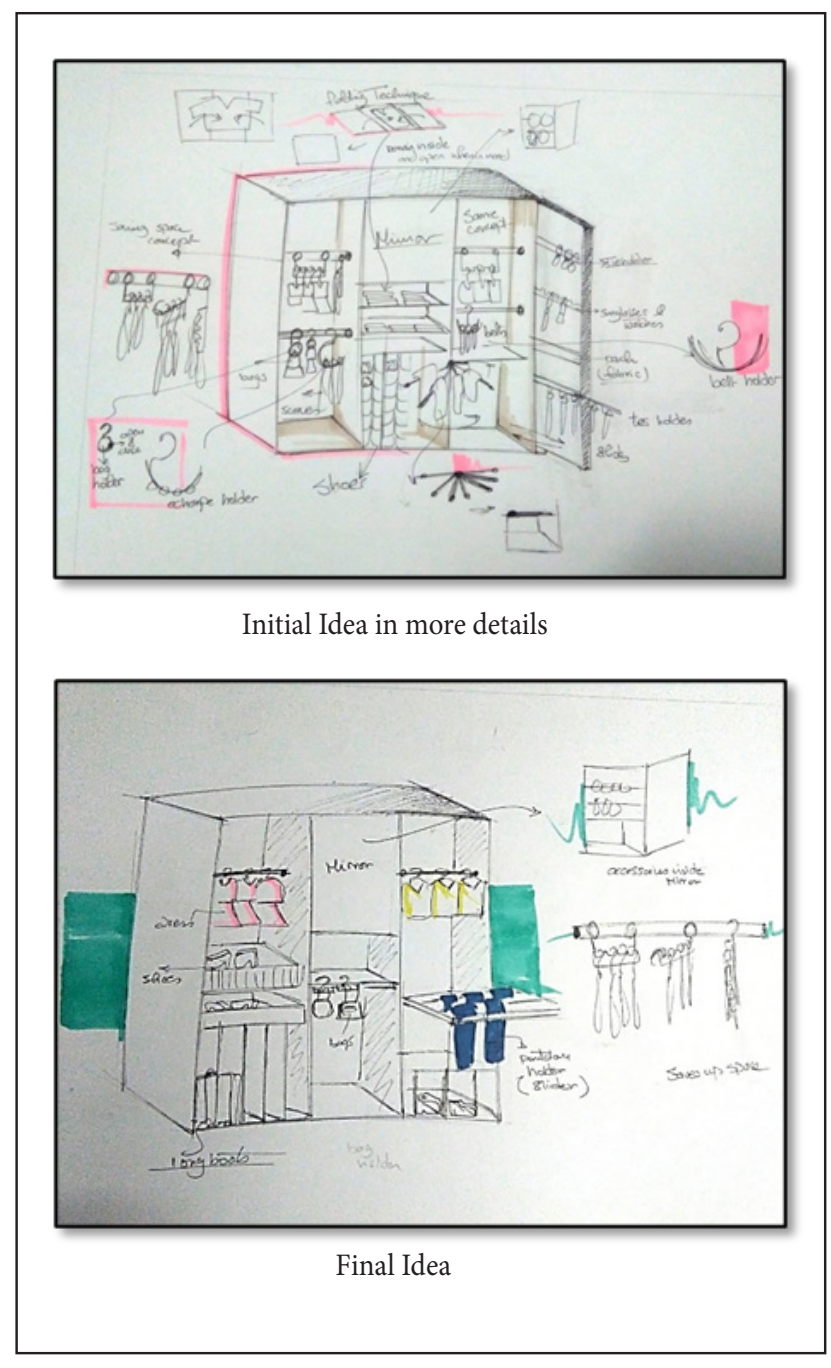

Figure 9: Final Idea

6-2-2 Team 2 (Messy fridge, needs to be organized)

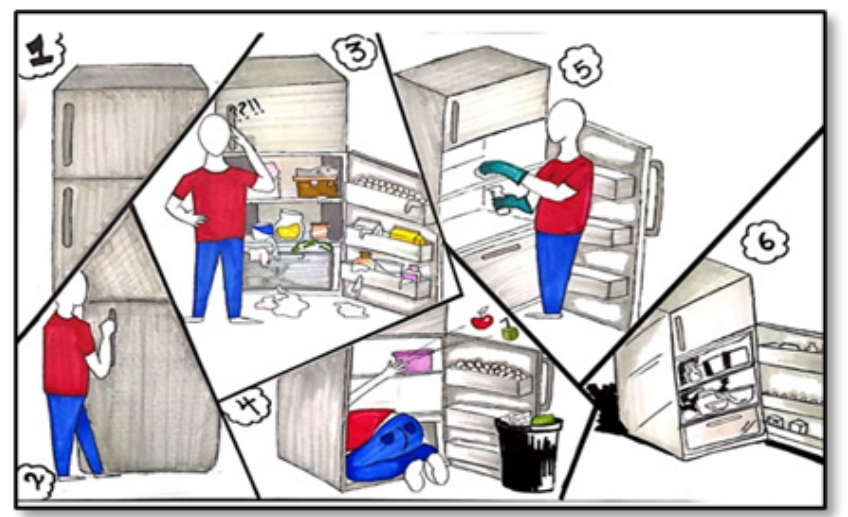

Figure 10: Scenario 


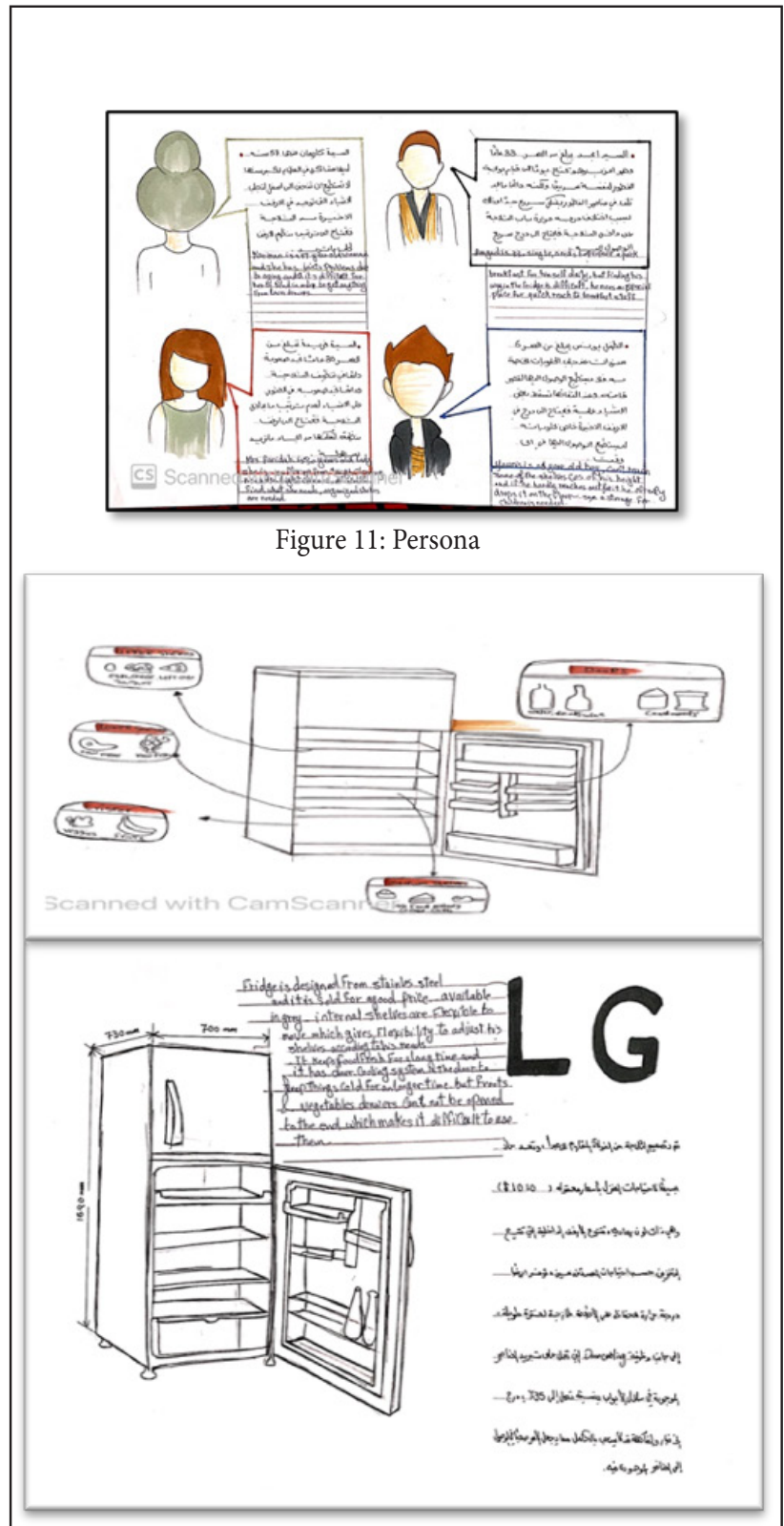

Figure 12: Product analysis
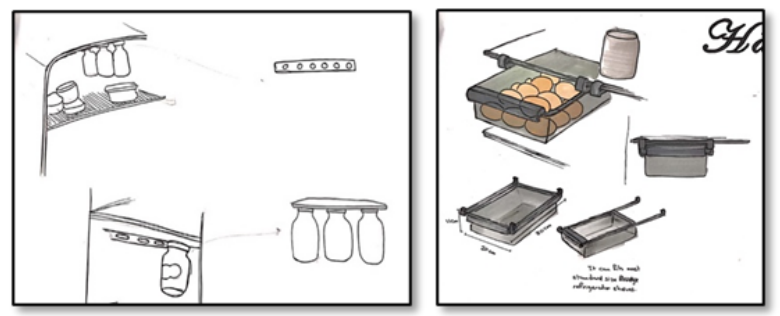

Figure 13: Final Idea
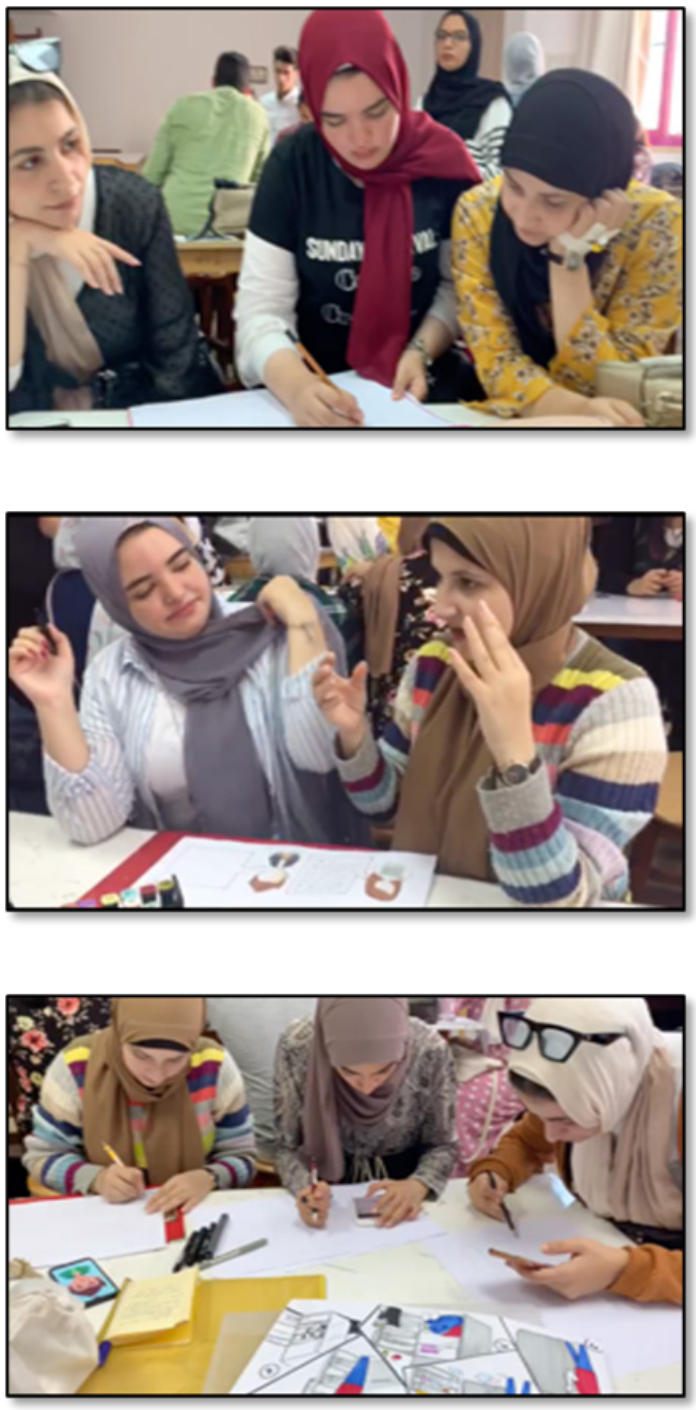

Figure 14: photos of the team during work sessions

\section{6-2-3 Team 3 (shoes are everywhere, storage needed}

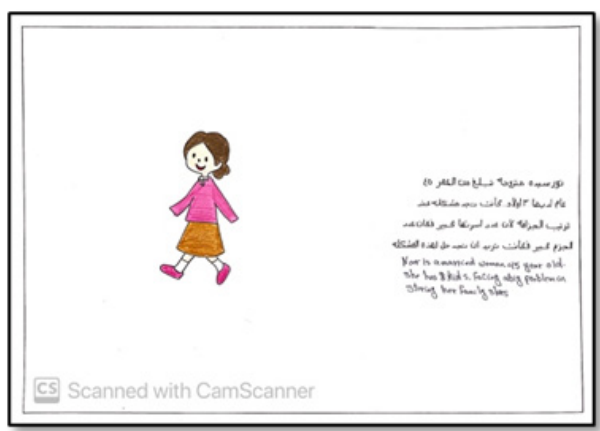

Persona 01 


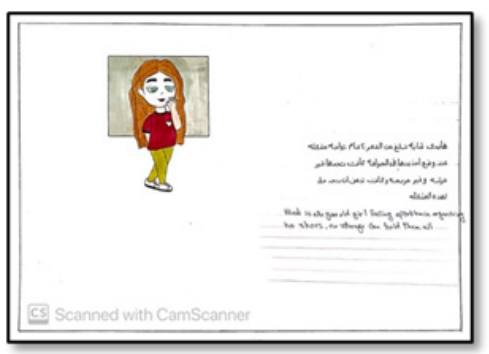

Persona 02

Figure 15: Persona
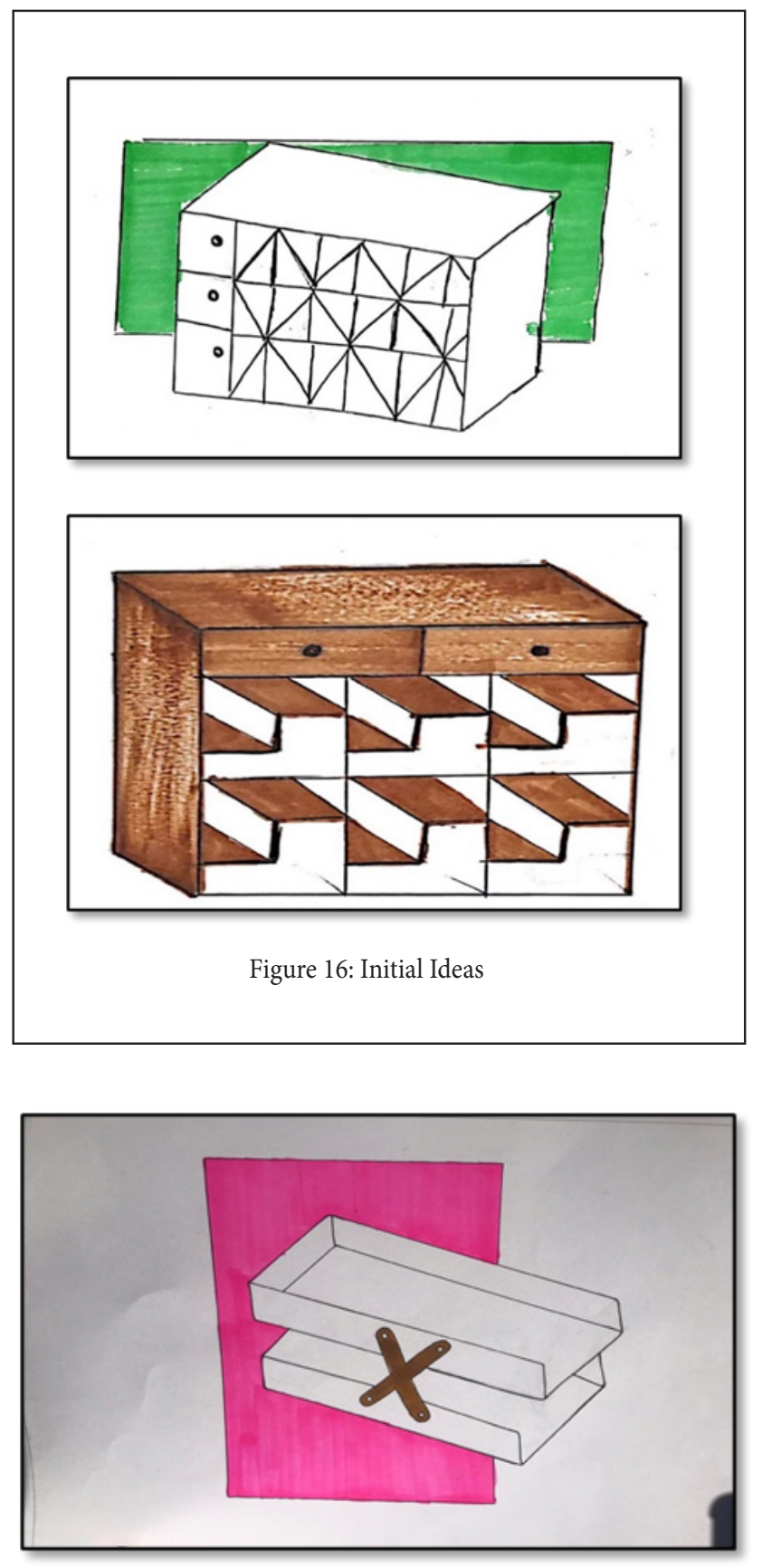

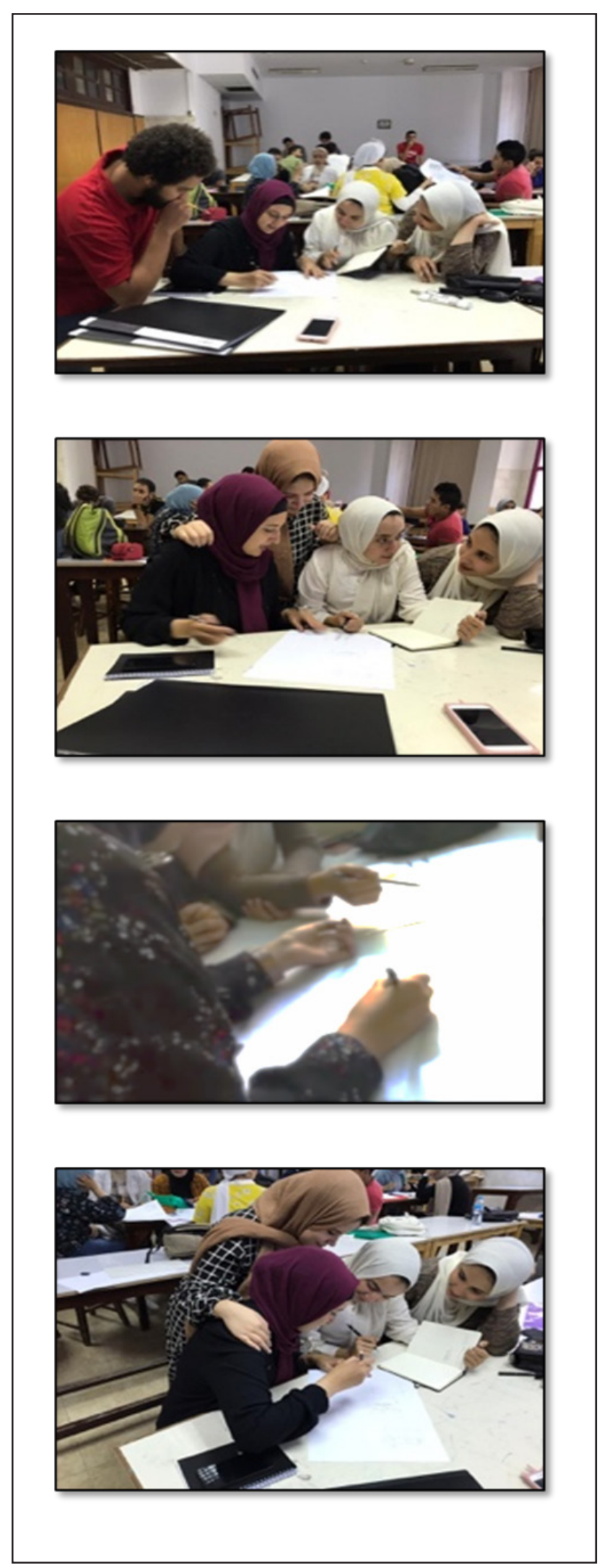

Figure 18: photos of the team during work sessions 
6-2-4 Team 4 (Messy student's desk)

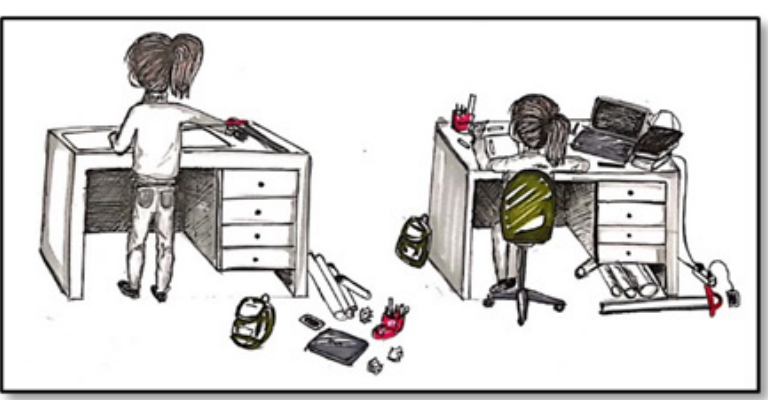

Figure 19: Scenario

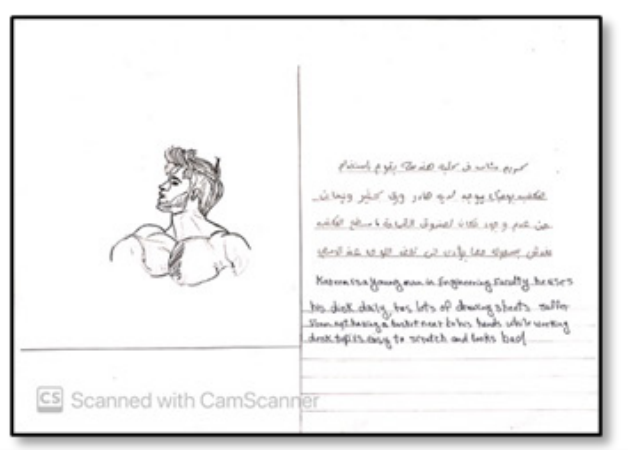

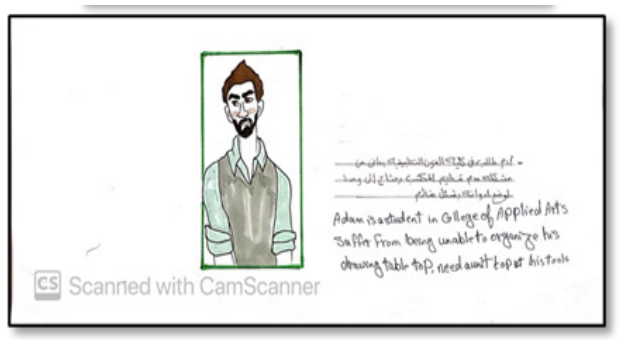
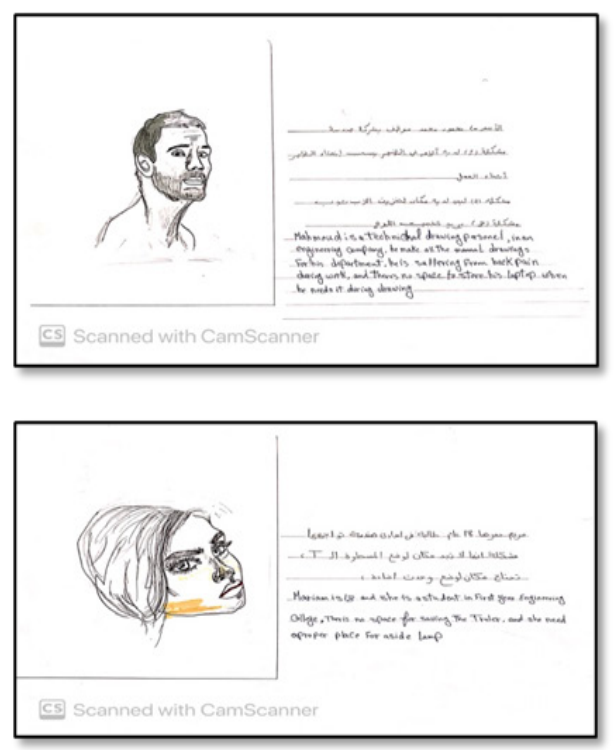

Figure 20: Persona

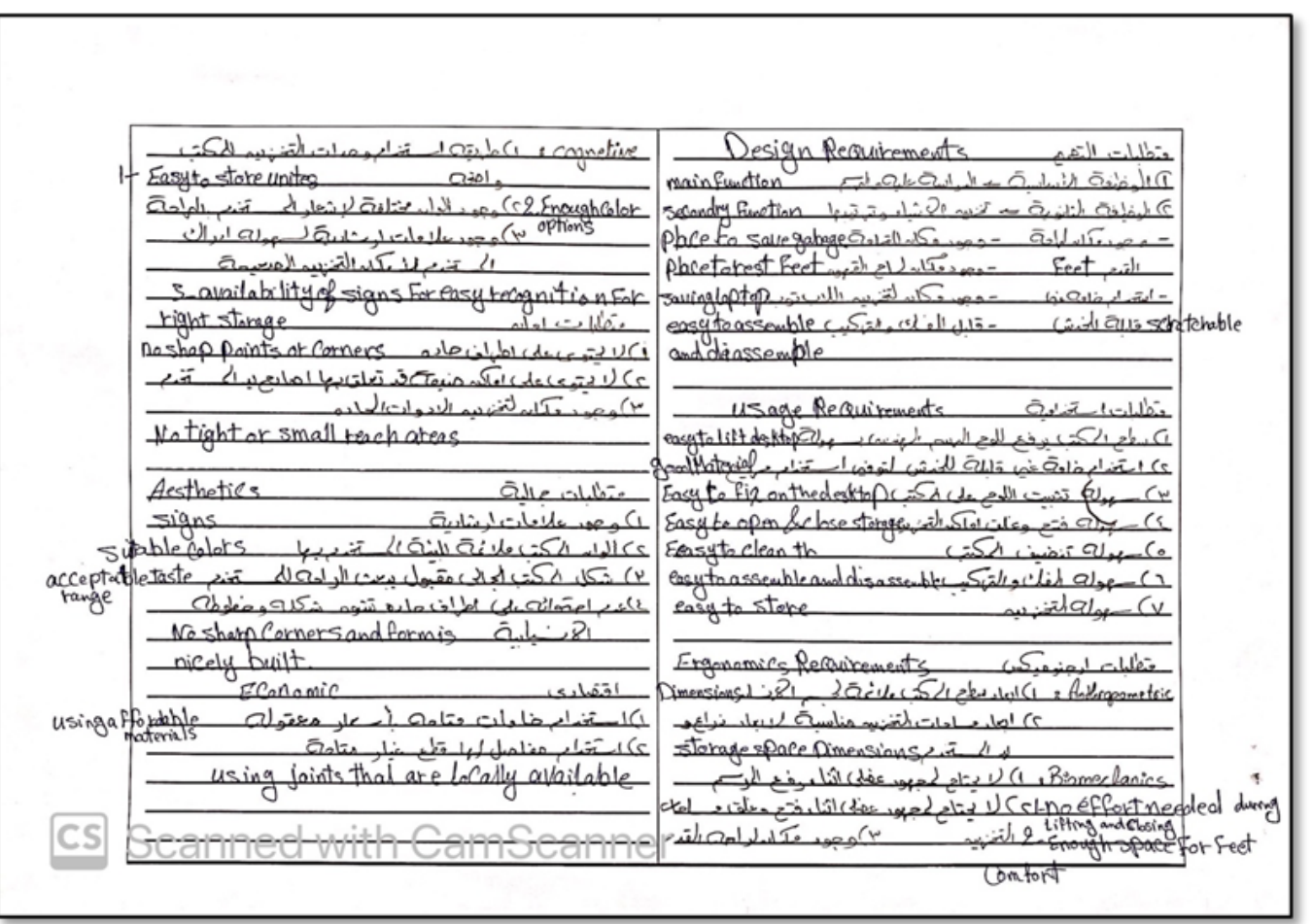

Figure 21: Final Design Requirements 


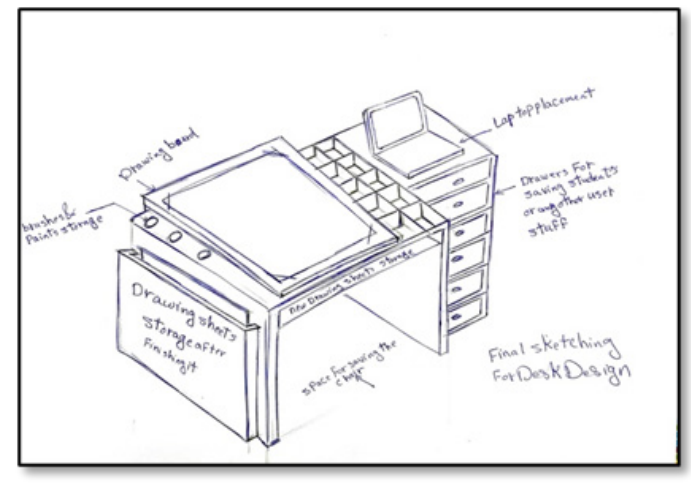

Figure 22: Final Idea

\section{6-3 Evaluating experiment}

As an instructor, the plan was to see the change of creativity level in the students 'work and their performance level in the final grand project, without direct interference in their Design challenge work, all the design phases were the same as what have been taught to them so, same procedures were followed easily.
Most of the groups followed the procedures and all the design phases were achieved the right way, the groups had a variety of students' skills, it was realized that the teams were formed wisely according to the needed skills, team leaders were the top of the class as designers, the rest of the teams included manual skills, knowledge of materials, quick thinkers, good researchers, the videos showed fast growth in self-confidence related to design thinking.

The study results had to be postponed till the final project work was done, it was noticed gradually that the presentation skills in general has improved, along with the discovery, and interpretation phases

The desire for improving the work increased rapidly for $75 \%$ (24 students) of the total students, the $25 \%$ (8 students didn't show any desire to improve their skills or strengthen their weakness points).

\begin{tabular}{|c|c|c|c|}
\hline $\begin{array}{c}\text { Team } \\
\text { No. }\end{array}$ & phase & What developments have been noticed & Remarks \\
\hline \multirow{4}{*}{1} & 1 & $\begin{array}{l}\text { Team1 showed strong search skills, and they distributed the } \\
\text { data search cleverly }\end{array}$ & $\begin{array}{l}\text { Team leader showed great self-steam } \\
\text { and made sure to understand her team } \\
\text { potentials }\end{array}$ \\
\hline & 2 & $\begin{array}{l}\text { Team leader did the interpretation and analysis, which was } \\
\text { almost problematic as the others didn't like the Idea of leaving } \\
\text { the results of that phase to be decided by } 1 \text { person }\end{array}$ & $\begin{array}{l}\text { The instructor advised the team leader } \\
\text { to avoid making decisions on behalf of } \\
\text { the team }\end{array}$ \\
\hline & 3 & $\begin{array}{l}\text { Having a creative team leader made the brainstorming stronger, } \\
\text { and sketching skills improved a lot among the team, final Idea } \\
\text { was successfully chosen }\end{array}$ & $\begin{array}{l}\text { That team included a student that } \\
\text { couldn't sketch well and a huge } \\
\text { development was noticed on her work }\end{array}$ \\
\hline & 4 & $\begin{array}{l}\text { The whole team prepared final documents together, and final } \\
\text { presentation was done by to students of the team }\end{array}$ & $\begin{array}{l}\text { Team leader was advised to choose two } \\
\text { of her team who has strong } \\
\text { communication skills. }\end{array}$ \\
\hline \multirow{4}{*}{2} & 1 & $\begin{array}{l}\text { Team } 2 \text { faced some problems in distributing search tasks, one } \\
\text { member didn't finish her task and the team leader did it on } \\
\text { behalf of her }\end{array}$ & $\begin{array}{l}\text { The instructor advised the student to } \\
\text { apology to her team and explain to } \\
\text { them why she didn't finish her task }\end{array}$ \\
\hline & 2 & Each team member did the analysis of her task & $\begin{array}{l}\text { The team leader gave the student who } \\
\text { didn't do her search task the two tasks } \\
\text { to analyze }\end{array}$ \\
\hline & 3 & $\begin{array}{l}\text { Sketching skills within that team was not reflected enough in } \\
\text { the quality of their Ideas and the ending result was similar to } \\
\text { existing products, but two of the team members who had week } \\
\text { sketching and idea building skills showed great development }\end{array}$ & $\begin{array}{l}\text { That team was advised to work more } \\
\text { on their creative thinking skills }\end{array}$ \\
\hline & 4 & $\begin{array}{l}\text { The whole team prepared final documents together, and final } \\
\text { presentation was done by to students of the team }\end{array}$ & $\begin{array}{c}\text { Team leader was advised to choose two } \\
\text { of her team who has strong } \\
\text { communication skills. }\end{array}$ \\
\hline
\end{tabular}




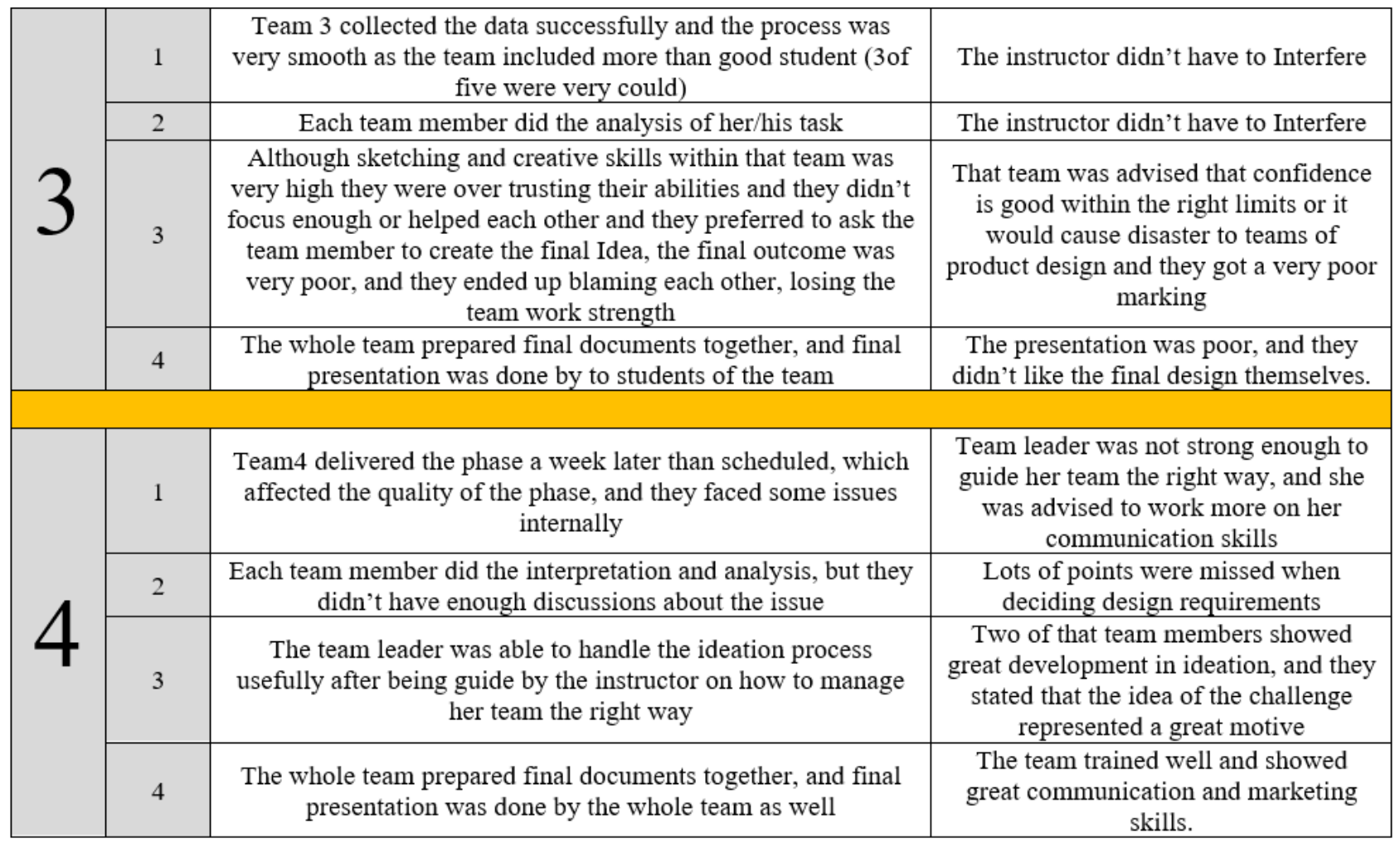

Table 4: Teams work review according to each design process

\section{7- Conclusions:}

- Design challenges done by teams from different students 'levels were beneficial to the weak students, as they were influenced by working side by side with the excellent students.

- the first two phases that needed hard work improved and that was clearly reflected in all the students work in their own projects.

- Team leaders played the role of mentors for their teams not just creative directors.

- creativity developed through deep understanding of the product along with imagination and intuition.

- Challenges made lecture time more appealing to $75 \%$ of the students

- Challenges made lecturer time management more controllable.

- Challenges can improve creativity skills within limits depending on the team members skills, the challenges topics and the students' own desire to improve.

\section{8- References}

1. Bono E ,Serious creativity: "Using the power of lateral thinking to great new ideas", HarperCollins, London, (1992).

2. Sternberg RJ, Lubart TI "Defying the crowd: Cultivating creativity in a culture of conformity", Free Press, New York, (1995).
3. Von OR, "A whack on the side of the head". Warner, New York, (1983)

4. Ledewitz, S., "Models of Design in Studio Teaching", Journal of Architectural Educa-tion, 38:2, 2-8, doi: 10.1080, (2014).

5. Morrow, R., Parnell, R. and Torrington, J., "Reality versus Creativity?" CEBE Transac-tions, (2004).

6. Osborn, Alex Faickney "Applied imagination", New York: Scribner, (1957)

7. Reid, A., \& Petocz, P.,. "Learning Domains and The Process of Creativity". The Austral-ian Educational Researcher, (2004).

8. Sutton, Robert I. \& Hargadon, Andrew. "Brainstorming Groups in Context: Effec-tivenes in a Product Design Firm”. Administrative Science Quarterly, (1996).

9. Vangundy, A. B., "101 Activities for Teaching Creativity and Problem Solving”. John Wiley \& Sons Inc, New York, United States, (2004).

10. Seval Özgel Felek, Ordu University, Özge Gül, Dogus University: "Design and Technology Education", International Journal, Turkey, (2018).

11. Shelli Walsh, "what is creativity", (C) Shelli Walsh, (2014).

12. Ryan Hargrove, University of Kentucky, Fostering creativity in the design studio: A framework towards effective pedagogical practices, 2010 .

Web sites:

13. https://www.designcouncil.org.uk/resources/casestudy/design-patient-dignity.

14. https://nicolecommander.com/3-interview-design-challenges/ 